This item was submitted to Loughborough's Research Repository by the author.

Items in Figshare are protected by copyright, with all rights reserved, unless otherwise indicated.

\title{
Emissive europium complexes that stain the cell walls of healthy plant cells, pollen tubes and roots
}

PLEASE CITE THE PUBLISHED VERSION

http://dx.doi.org/10.1039/c3ra45426f

\section{PUBLISHER}

(C) The Royal Society of Chemistry

\section{VERSION}

AM (Accepted Manuscript)

\section{PUBLISHER STATEMENT}

This work is made available according to the conditions of the Creative Commons Attribution-NonCommercialNoDerivatives 4.0 International (CC BY-NC-ND 4.0) licence. Full details of this licence are available at: https://creativecommons.org/licenses/by-nc-nd/4.0/

\section{LICENCE}

CC BY-NC-ND 4.0

\section{REPOSITORY RECORD}

Palmer, Antony J., Susan H. Ford, Stephen J. Butler, Timothy J. Hawkins, Patrick J. Hussey, Robert Pal, James W. Walton, and David Parker. 2019. "Emissive Europium Complexes That Stain the Cell Walls of Healthy Plant Cells, Pollen Tubes and Roots". figshare. https://hdl.handle.net/2134/18763. 


\title{
Emissive europium complexes that stain the cell walls of healthy plant cells, pollen tubes and roots
}

\author{
Antony J. Palmer, ${ }^{\mathrm{a}, \mathrm{b}}$ Susan H. Ford, ${ }^{\mathrm{a}, \mathrm{b}}$ Stephen J. Butler, ${ }^{\mathrm{a}}$ Timothy J. Hawkins, ${ }^{\mathrm{b}}$
}

Patrick J. Hussey ${ }^{\mathrm{b}}$, Robert Pal ${ }^{\mathrm{a}}$, James W. Walton ${ }^{\mathrm{a}}$ and David Parker $*^{\mathrm{a}}$

a) Department of Chemistry, Durham University, South Road, Durham, DH1 3LE, UK.

b) School of Biological Sciences, Durham University, South Road, Durham, DH1 3LE, UK.

The cell-staining behaviour of a set of five emissive europium complexes has been studied in Nicotiana tabacum BY-2 cells and pollen tubes, Nicotiana benthamiana plant leaves and in the root hairs of the wild-type plant Arabidopsis thaliana (Columbia). The cell walls were stained selectively, notably in the tobacco BY-2 cells, by the complex $\left[\mathrm{EuL}^{1}\right]$ that contains one azathiaxanthone chromophore. Internalisation only occurred in cells that had been deliberately permeabilised or were dying. No uptake was observed within healthy plant leaves. In root hairs, the cell wall was strongly stained as well as the mitochondria, revealed by time-lapsed microscopy that showed the tumbling of the mitochondria in the living tissue, confirmed by co-localisation studies. In pollen tubes, the cell wall was also stained; rapid bursting of the pollen tip occurred following incubation with [Eu.L ${ }^{1}$ ], triggered by excitation with $405 \mathrm{~nm}$ laser light. Such behaviour is consistent with local perturbation of cell wall permeability and integrity, associated with the reactivity of the chromophore triplet excited state.

\section{Introduction}

Luminescence imaging in plants presents unique challenges as staining is complicated by endogenous autofluorescence and the impermeability of the cell wall to exogenous protein-based fluorophores, labeled antibodies and many low MW probes. The impermeability of cell walls, due to their cellulose rich composition, provides a challenge if protein based stains, such as labelled antibodies, or other large molecules are used. Autofluorescence arises from a variety of plant biomolecules; the main contributor is chlorophyll, which absorbs in the blue region of the visible spectrum with a high molar extinction coefficient, and emits above $600 \mathrm{~nm}$.

Several approaches have been developed to reduce autofluorescence, such as the use of methacrylate when fixing cells. ${ }^{1}$ However, this is only suitable for static, fixed samples and not for the dynamic study of living cells. Alternatively, it is possible to use stains that do not absorb and emit in the same region as the endogenous chromophores responsible for the autofluorescence and to use a line pass 
filter set, e.g. a LP450 filter, for excitation. ${ }^{2}$ The use of time-resolved microscopy with longer-lived (orders of $\mathrm{ms}$ ) probes offers much scope for selective probe observation as time-gating removes short-lived (orders of ns) endogenous fluorescence and light scattering.

There is a range of organelles in plant cells, in common with all eukaryotes, that form an assortment of functionally different compartments. The large structures of the endoplasmic reticulum, Golgi apparatus, and vacuoles have all been well characterized with scanning electron microscopy. However, a number of small, dynamic compartments exist, such as pre-vacuolar compartments and early endosomes that had been identified but could not be characterised until recently, when specific markers for them were found. ${ }^{3}$ Transgenic tobacco BY-2 cells and Arabidopsis plants expressing GFP fusion proteins were devised that localised to these compartments. ${ }^{4}$ These markers have the usual drawbacks, as discussed above, but are an established tool in studying dynamic plant structures. ${ }^{5}$ Further compartments are likely to exist that are involved in the secretory, endocytotic and exocytotic pathways but remain undiscovered. These will require the development of novel luminescent markers.

Significant developments have occurred in lanthanide probe chemistry over the last two decades ${ }^{6,7}$, notably in their interactions with biosystems. ${ }^{8}$ Lanthanides are found only in trace amounts in natural systems and serve no active role in biology, meaning that there is no interference from endogenous signals. ${ }^{9}$ The use of welldesigned lanthanide complexes as probes for spectroscopy ${ }^{10}$ or microscopy ${ }^{11}$ can be advantageous due to their unique properties. They exhibit long-lived emission, allowing for sensitive time-gated detection ${ }^{12}$ (well-defined, narrow peaks in the emission spectrum allow for more complex analysis), and have large Stokes' shifts, of hundreds of nanometres. Several examples exhibit dynamic responses to local conditions such as $\mathrm{pH}$ or bicarbonate ${ }^{13}$, allowing the measurement of these parameters within particular organelles of mammalian cells. The cell-uptake and localisation behaviour of several series of complexes have been characterised, allowing structurelocalisation correlations to be made, based on the nature and linkage mode of the sensitising moiety, as it is this moiety that primarily controls their uptake (most often by macropinocytosis), egress, and transport behaviour. ${ }^{14-19}$

In this work, we have set out to examine the staining behaviour of a set of five lanthanide probes (Scheme 1), amenable to excitation at 355 (Nd:YAG) or 405 (diode 
laser) nm, for microscopy studies in Nicotiana tabacum BY-2 cells and pollen tubes, Nicotiana benthamiana plant leaves and in the root hairs of the wild type plant Arabidopsis thaliana. The Bright Yellow 2 (BY-2) cells have become the most widely used plant cell culture, due to their desirable characteristics of high growth rate and homogeneity. They are easy to culture and maintain indefinitely, relatively simple to manipulate genetically, and offer a powerful tool in plant molecular biology due to the ease of transformation to form stable transgenic lines ${ }^{20}$. A benefit of BY-2 cells is that when grown in the dark they do not produce chlorophyll, which greatly mitigates against autofluorescence. Furthermore, it is easy to make protoplasts from a BY-2 cell culture by using a cocktail of enzymes to degrade the cell wall, which can be used to help a dye penetrate the cell. They are the most widely used model plant cell line and a set of non-perturbing dyes that can be added to the live cells to co-stain and confirm localization is desirable, while allowing for study of dynamic processes.

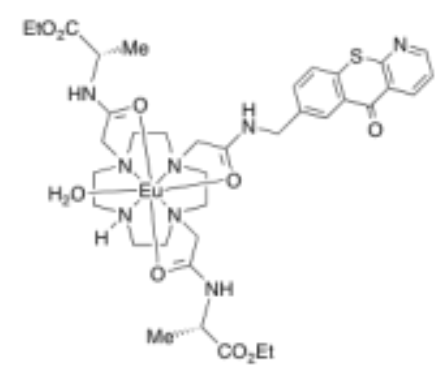

$\left[\mathrm{Eu} . \mathrm{L}^{1} \mathrm{OH}_{2}\right]^{3+}$

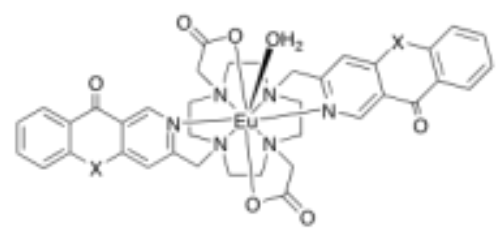

$\left[\mathrm{Eu} . \mathrm{L}^{2} \mathrm{OH}_{2}\right]^{+}$

a) $X=O$

b) $\mathrm{X}=\mathrm{S}$

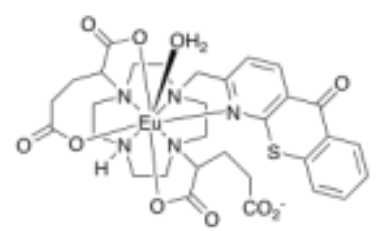

$\left[\mathrm{Eu} . \mathrm{L}^{3} \mathrm{OH}_{2}\right]^{-}$

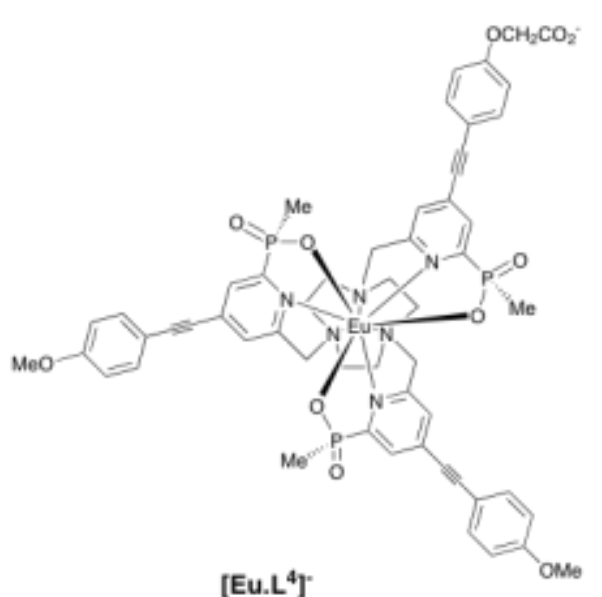

[Eu.L']

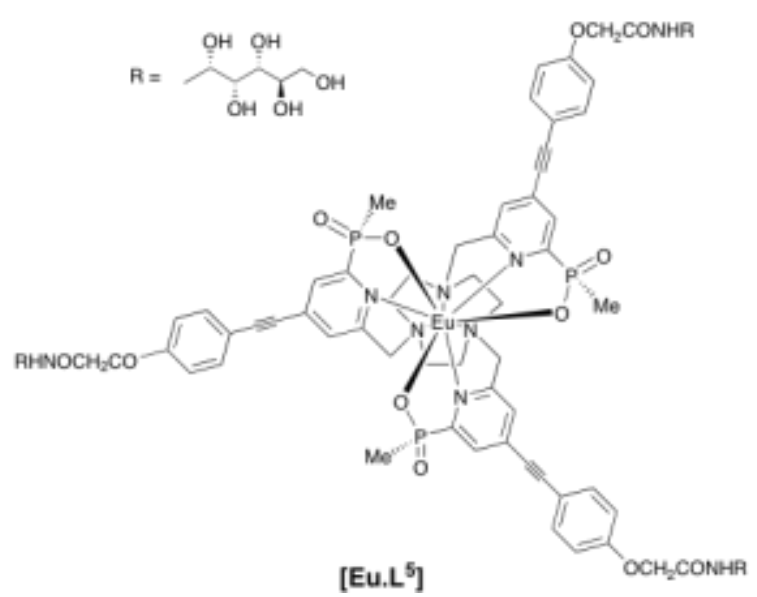

Scheme $1 \quad$ Structure of the Eu complexes examined in this study

\section{Results and Discussion}

Probe synthesis 
The europium probes examined (Scheme 1) possess either an azathiaxanthone sensitising moiety or an aralkynylpyridyl moiety. ${ }^{21,23,24}$ The latter pair of complexes are very bright $\left(B=\varepsilon \times \phi=30 \mathrm{mM}^{-1} \mathrm{~cm}^{-1}\right)$ and can be excited at 355 or $365 \mathrm{~nm}$. It is known that azathiaxanthones have absorption maxima that extend to over $400 \mathrm{~nm}$, making them better suited for use with common microscopy equipment and also of potential use in two photon excitation studies. ${ }^{21}$ Notwithstanding their longer absorption wavelength, the azathiaxanthones possess a smaller singlet-triplet energy gap than the azaxanthones. ${ }^{22}$ As a result, azathiaxanthones triplet energies are in the range suitable for sensitisation of $\mathrm{Eu}^{3+}$, although $\mathrm{Tb}^{3+}$ sensitisation is very inefficient, and sensitive to oxygen and temperature variation. Europium complexes with integral azathiaxanthone sensitisers possess dual emission: short-lived fluorescence around $440 \mathrm{~nm}\left(\tau_{\mathrm{f} 1} 1.7 \mathrm{~ns}, \phi_{\mathrm{fl}}\right.$ between 40 and $\left.50 \%\right)$, accompanied by the characteristic longlived europium emission in the range 580 to $710 \mathrm{~nm} .{ }^{22}$

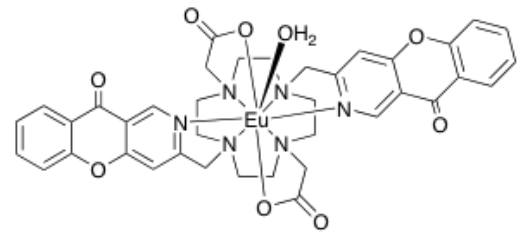

$\left[\text { Eu. }{ }^{2 \mathrm{a}}\left(\mathrm{H}_{2} \mathrm{O}\right)\right]^{+}$

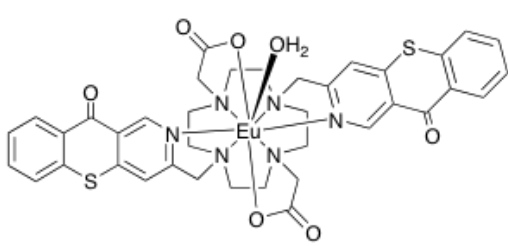

$\left[\mathrm{Eu} . \mathrm{L}^{2 \mathrm{~b}}\left(\mathrm{H}_{2} \mathrm{O}\right)\right]^{+}$

Table 1. Photophysical data for $\left[\mathrm{Eu} . \mathrm{L}^{2 \mathrm{a}}\right]^{+}$and $\left[\mathrm{Eu} . \mathrm{L}^{2 \mathrm{~b}}\right]^{+}\left(\mathrm{H}_{2} \mathrm{O}, 295 \mathrm{~K}\right)$, compared to the complexes used in this study

\begin{tabular}{lcllllc}
\hline Complex & $\lambda_{\text {abs }} / \mathrm{nm}$ & $\varepsilon / \mathrm{M}^{-1} \mathrm{~cm}^{-1}$ & $\tau / \mathrm{ms},\left(\mathrm{D}_{2} \mathrm{O}\right)$ & $\tau / \mathrm{ms},\left(\mathrm{H}_{2} \mathrm{O}\right)$ & $\mathrm{q}$ & $\phi_{\mathrm{em}} / \%$ \\
\hline$\left[\mathrm{Eu} . \mathrm{L}^{1}\left(\mathrm{H}_{2} \mathrm{O}\right)\right]^{3+}$ & 384 & 12,800 & 0.90 & 0.44 & 1.0 & 5.0 \\
{$\left[\mathrm{Eu} . \mathrm{L}^{2 \mathrm{a}}\left(\mathrm{H}_{2} \mathrm{O}\right)\right]^{+}$} & 328 & 5,800 & 1.70 & 0.65 & 1.1 & 10 \\
{$\left[\mathrm{Eu} . \mathrm{L}^{2 \mathrm{~b}}\left(\mathrm{H}_{2} \mathrm{O}\right)\right]^{+}$} & 368 & 6,200 & 1.76 & 0.63 & 1.1 & 8.3 \\
{$\left[\mathrm{Eu} . \mathrm{L}^{3}\left(\mathrm{H}_{2} \mathrm{O}\right)\right]^{-}$} & 380 & 4,070 & $0.59^{\mathrm{b}}(0.63)$ & $0.30^{\mathrm{b}}(0.29)$ & 1.0 & 1.2 \\
{$\left[\mathrm{Eu} . \mathrm{L}^{4}\right]^{-}$} & 330 & 60,400 & 1.30 & 1.04 & 0 & $49^{\mathrm{a}}$ \\
{$\left[\mathrm{Eu} . \mathrm{L}^{5}\right]$} & 328 & 56,500 & 1.31 & 1.07 & 0 & $50^{\mathrm{a}}$ \\
\hline
\end{tabular}

${ }^{\mathrm{a}}$ In methanol solution. ${ }^{\mathrm{b}}$ Values in parenthesis refer to $\mathrm{pH} 8$, values quoted refer to $\mathrm{pH} 3.5$. 


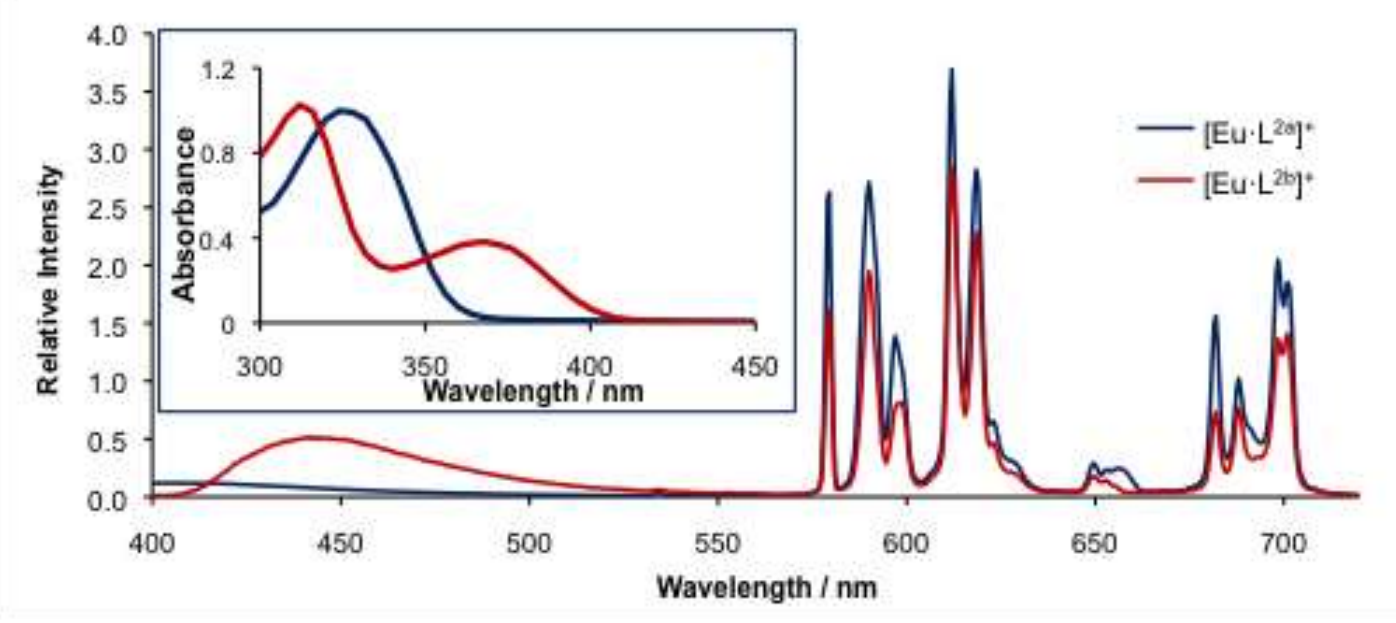

Figure 1 Absorption and total emission spectra for $\left[\text { Eu.L } \mathrm{L}^{2 \mathrm{a}}\right]^{+}$(blue) and $\left[\mathrm{Eu} . \mathrm{L}^{2 \mathrm{~b}}\right]^{+}$(red) (295K, water).

The complex $\left[\mathrm{Eu} . \mathrm{L}^{2 \mathrm{~b}}\right]^{+}$has not been reported previously, whilst the synthesis and characterisation of the other complexes studied have been described. ${ }^{21,23,24}$ The

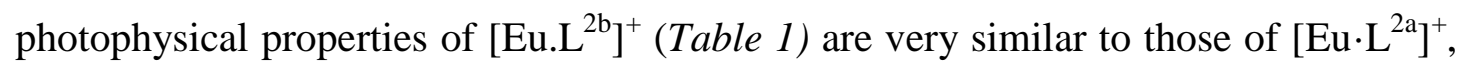
with the exception of its absorbance spectral profile. The absorption spectrum of $\left[\mathrm{Eu} \cdot \mathrm{L}^{2 \mathrm{~b}}\right]^{+}$(Figure 1) shows two maxima at $310 \mathrm{~nm}\left(\varepsilon=12,000 \mathrm{M}^{-1} \mathrm{~cm}^{-1}\right)$ and $368 \mathrm{~nm}$ ( $\varepsilon=6,200 \mathrm{M}^{-1} \mathrm{~cm}^{-1}$ ), attributed to transitions with dominant $\mathrm{n}-\pi^{*}$ and $\pi-\pi^{*}$ character. The emission spectra of $\left[\mathrm{Eu} \cdot \mathrm{L}^{2 \mathrm{~b}}\right]^{+}$and $\left[\mathrm{Eu} \cdot \mathrm{L}^{2 \mathrm{a}}\right]^{+}$were measured following excitation at their absorption maxima, (Fig 1). The form of the europium spectral emission (580 to $710 \mathrm{~nm}$ ) is very similar, indicating that the symmetry and coordination environment about $\mathrm{Eu}^{3+}$ is the same in each case. This is confirmed by the measured hydration number $(q)$ values of 1.1 for each complex. A second observation is the increased fluorescence centred at $440 \mathrm{~nm}$ for the azathiaxanthone analogue. The fluorescence emission makes up $37 \%$ of the total observed emission, with a lifetime of $1.7 \mathrm{~ns}$. The significant amount of fluorescence suggests that the radiative rate constant for fluorescence emission is greater for the azathiaxanthone complex compared to the azaxanthone analogue. ${ }^{22 a}$

\section{Staining of tobacco BY-2 cells}

Several different samples of BY-2 cells were examined and incubated with concentrations of up to $100 \mu \mathrm{M}$ of $\left[\mathrm{Eu} \cdot \mathrm{L}^{\mathrm{n}}\right](\mathrm{n}=1,2 \mathrm{~b}, 3$ and 5). The azathiaxanthone complexes were studied in more detail here, as they can be excited at $405 \mathrm{~nm}$ on most fluorescence microscopes. Cells from three different wild type lineages (BY2-1, BY22 and BY2-JI), and two transgenic cell lines (GFP-Lifeact and GFP-TDP6) were examined. Internalisation of the probe was examined by confocal microscopy and the only occasions that luminescence from the lanthanide complex was observed occurred 
with plasmolysed cells that were dead or in the process of dying. On all other occasions, only the cell wall was stained (Figure 2). Attempts to encourage uptake of $\left[\mathrm{Eu} . \mathrm{L}^{1}\right]$ and $\left[\mathrm{Eu} . \mathrm{L}^{3}\right]$ by deliberate permeabilisation were undertaken. Using either $2 \%$ DMSO or $1.5 \%$ glycerol, added to the cells before incubation with the complex (20 min.), uptake of every dye under investigation was observed, with staining within the nucleus and cytoplasm. These conditions are known to destabilize cell membranes, and therefore as such conditions necessarily perturb cell homeostasis too much, further investigations were not conducted.

Protoplasts were made from the BY-2 cell culture, to assess whether the cell wall or plasma membrane was key to blocking entry. After the cell wall was degraded overnight, $\left[\mathrm{Eu} . \mathrm{L}^{1}\right]$ was incubated with the protoplasts for $20 \mathrm{~min}$ and they were imaged. Spherical cells were observed that did not stain with Calcofluour (which binds to cellulose and so would stain the cell wall if it had not been digested), signalling that the "protoplasting" procedure was successful. The dye did not stain or penetrate the protoplast cell membrane, although it was clearly visible in the medium around the cell. Furthermore, the dye MitoTracker was still able to penetrate and label the mitochondria of protoplasts, suggesting that the cells were behaving 'normally', and were not abnormally impermeable.

Figure 2 Upper: Confocal microscopy images showing the selective staining of the cell wall of tobacco BY-2 cells; left: [Eu.L ${ }^{1}$ ] following a 30 minute incubation $\left(r e d, 50 \mu \mathrm{M}, \lambda_{\text {exc }} 355 \mathrm{~nm} ; \lambda_{\mathrm{em}} 605\right.$ $720 \mathrm{~nm}$ ); centre: the organic dye FM4-64 (green, $100 \mathrm{nM}, \lambda_{\mathrm{exc}} 488 \mathrm{~nm} ; \lambda_{\mathrm{em}} 650$ - 750); right RGB merge co-localised image showing correspondence $(\mathrm{P}=0.91)$. Lower: left: $10 \mathrm{~min}$ incubation (red, 50 $\left.\mu \mathrm{M}\left[\mathrm{Eu} . \mathrm{L}^{1}\right]\right)$ outlines the cell, staining the cell wall selectively; right: with 10 min incubation MitoTracker Green $\left(100 \mathrm{nM}, \lambda_{\mathrm{exc}} 488 \mathrm{~nm} ; \lambda_{\mathrm{em}} 505-550 \mathrm{~nm}\right)$ the location of the mitochondria is revealed and the overlay shows that $\left[\mathrm{Eu} . \mathrm{L}^{1}\right]$ clarifies the location of the cell. Bottom: left: time-gated epifluorescence image ( $\lambda_{\text {exc }} 365 / 10 \mathrm{~nm} ; \lambda_{\mathrm{em}} \mathrm{LP} 570 \mathrm{~nm} ; \mathrm{t}_{\mathrm{g}} 10 \mu \mathrm{s}, \mathrm{t}_{\mathrm{acq}} 5 \mathrm{~ms}, 500$ acq. image), of tobacco

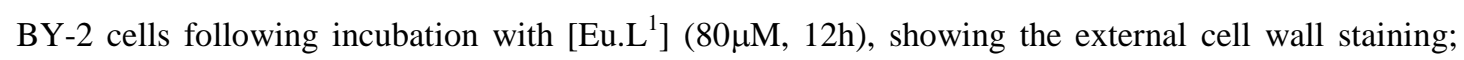
right: time-gated emission spectrum ( $\lambda_{\text {exc }} 365 \mathrm{~nm} ; \mathrm{t}_{\mathrm{g}} 10 \mu \mathrm{s}, \mathrm{t}_{\mathrm{acq}} 1 \mathrm{~ms}, 1000$ avg. cycle) extracted from the same field of view showing the profile typical of the intact complex. Insert: lifetime decay $\left(\tau_{\mathrm{Eu}}=\right.$ $\left.0.35 \mathrm{~ms}, \lambda_{\varepsilon x \mathrm{c}} 365 \mathrm{~nm} ; \lambda_{\mathrm{em}} 620 / \pm 20 \mathrm{~nm}\right)$.

Although it was obvious that the compounds were not entering living cells, it can be seen from the images that there is a strong signal outlining the cell. A co-localisation experiment using [Eu.L ${ }^{1}$ ] and the amphiphilic styryl dye, FM 4-64, (an established membrane stain) ${ }^{25}$ was undertaken (Figure 2). In dead or dying cells, the europium complex also stains the shrunken cytoplasm and also the cell wall, which remains rigidly in place. This shows that the complexes are an effective stain for the outline of living cells. In a co-stain with MitoTracker-Green, the mitochondria are clearly labelled, and $\left[\mathrm{Eu} . \mathrm{L}^{1}\right]$ is able to outline the cell and give a clear picture of each individual cell and its shape. No time dependent (10min $-24 \mathrm{~h})$ localization or change in image brightness was observed throughout these experiments.

The amount of Eu complex internalized was assessed using ICP-mass spectrometry, using previously reported methods. ${ }^{19}$ Following an incubation of $\left[\mathrm{Eu} . \mathrm{L}^{1}\right]$ and $\left[\mathrm{Eu} . \mathrm{L}^{2 \mathrm{~b}}\right]$ $(25 \mu \mathrm{M})$ with BY-2 cells for $24 \mathrm{~h}$, it was found that the concentration of Eu associated with the isolated, washed cells was $200 \mu \mathrm{M}$ and $6 \mu \mathrm{M}$ respectively, consistent with

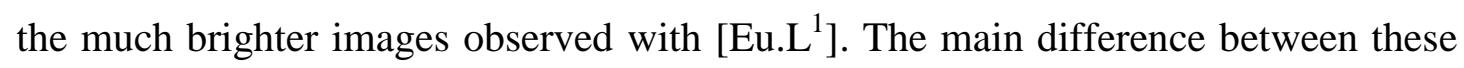
two azathiaxanthone europium complexes is that $\left[\mathrm{Eu} . \mathrm{L}^{1}\left(\mathrm{H}_{2} \mathrm{O}\right)\right]^{3+}$ can bind reversibly at the Eu centre to certain anions and to protein with displacement of the coordinated water molecule. Such processes alter the Eu emission spectral fingerprint, although the changes with this particular complex are less significant than with analogous systems that lack the macrocyclic ring N-methyl group. ${ }^{23}$ In contrast, the Eu complex of $\mathrm{L}^{2 \mathrm{~b}}$ has eight ligand donor atoms and one coordinated water that is not displaced in 
aqueous media by either anions or protein. Therefore, the differing extent of Eu uptake is likely to be related to these intrinsic intermolecular binding properties. ${ }^{\text {6e }}$

A second application of such stains could be in cell viability assays with BY-2 cells. Only dead, dying or chemically compromised cells show luminescence within their cytoplasm, and so [Eu.L $\left.{ }^{1}\right]$ and the other complexes under investigation could be used to identify whether a population of cells is healthy or not. A set of healthy cells will give rise to a luminescent outline around each cell, while dead and dying cells will show signal throughout their cytoplasm and nucleus. Such properties are similar to the behaviour of common live/dead cell assays, e.g. using Trypan Blue or eosin.

\section{Studies with plant tissues}

The two systems investigated were leaf tissue from Nicotiana benthamiana, a relative of tobacco and a model organism used for agroinfiltration ${ }^{26}$ and in the study of pests. Secondly, root hairs were examined from Arabidopsis thaliana, the most commonly studied plant ${ }^{27}$ and an ideal candidate for live cell imaging. ${ }^{28}$

After infiltration with a solution of $\left[\mathrm{Eu} . \mathrm{L}^{1}\right]^{3+}(100 \mu \mathrm{M})$, no entry into the cells within the leaf tissue was seen, (Figure 3), and the other Eu complexes in this study behaved similarly. The only visible luminescence was in the extracellular spaces, which highlighted the 'paving-slab' patterning of the epidermal cells. This result makes sense intuitively: the leaves are not an absorption surface and are a vital tissue to the plant, being the site of photosynthesis and transpiration. They are a target for herbivores and pests and so are adapted to be a barrier to entry. Furthermore, fullygrown cells develop a secondary hydrophobic cell wall containing lignin to give extra strength and waterproofing. The fact that these cells are impermeable to the Eu complexes again raises the possibility of using them as dyes to assess cell viability. For example, leaves may be made permeable under pathogen attack and $\left[\mathrm{Eu} . \mathrm{L}^{1}\right]^{3+}$ could show the extent of damage by revealing those cells remaining in a healthy state.
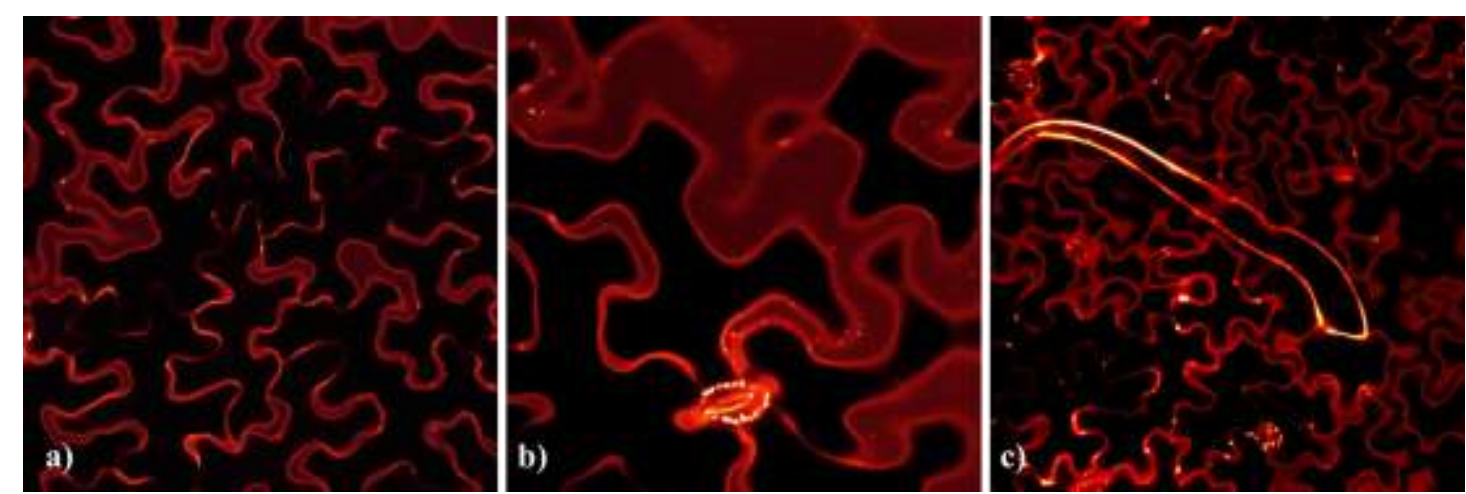
Figure 3 Luminescence observed by confocal microscopy $\left(\lambda_{\mathrm{exc}} 405 \mathrm{~nm} ; \lambda_{\mathrm{em}} 570-720 \mathrm{~nm}\right)$ from $\left.[\text { Eu.L }]^{1}\right]^{3+}$ infiltrated into a Nicotiana benthamiana leaf: a) luminescence fills the extracellular spaces without entering the epidermal cells; b) at higher magnification, no strong luminescence is seen apart from that associated with autofluorescence from the stoma at the bottom of the image. Stomata are responsible for the bright spots in the other two images; c) strong autofluorescence is seen from the trichome through the centre of the image, and the complex does not enter the cells.

The root hairs were incubated with up to a $100 \mu \mathrm{M}$ solution of each Eu complex for 30 minutes before they were imaged. Every complex outlined the surface of the root hairs, staining the cell walls in a similar manner to that observed with BY-2 cells. With $\left[\mathrm{Eu} . \mathrm{L}^{1}\right]^{3+}$, luminescence was observed in small mobile organelles. These were observed in time-lapsed images (see ESI for a video) to rapidly tumble within the cytoplasm. By acquiring images at the rate of one per second, it was possible to see them being streamed through the cytoplasm towards the tip of the root hair. Such behaviour is typical of plant root mitochondria, and their high number, size and morphology match those of mitochondria and root hairs. Co-staining with MitoTracker Green lent direct support to this hypothesis (Figure 4). Root hairs are known to have a high number of mobile mitochondria, in order to generate the ATP required for active transport of nutrients from the soil.

Luminescence was also observed from larger aggregates within the root hair. These may be collections of immobile mitochondria or more-general debris. Using $\left[\mathrm{EuL}^{\mathrm{n}}\right](\mathrm{n}=2 \mathrm{~b}, 3)$ no particular sub-cellular compartment was stained, but the complexes were able to enter the root hairs and label large static aggregates within the cell. The carbohydrate conjugate complex, $\left[\mathrm{Eu} . \mathrm{L}^{5}\right]$ did not enter the root hair at all. On the other hand, the structurally similar very bright complex, $\left[\mathrm{Eu} . \mathrm{L}^{4}\right]^{-}$did stain the root membrane sufficiently well to allow recording of its time-gated image, using time-gated epifluorescence microscopy. Furthermore, the characteristic emission spectral and lifetime profile of the complex was obtained in the roots, using timegated spectral imaging techniques. (Figure 5). Such behaviour indicates that the coordination environment at Eu does not change upon internalization. The differing behaviour of the Eu complexes in root uptake and staining is not readily rationalised and further experiments will be needed to understand why the observed uptake and staining profiles occur. 

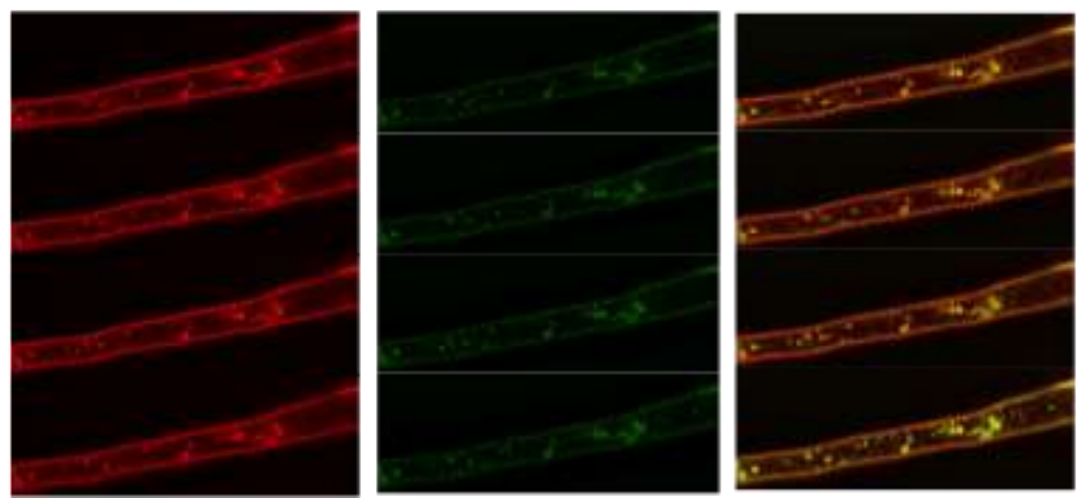

Figure 4 Confocal microscopy images showing co-localisation with MitoTracker-Green (100 nM) and $\left[\mathrm{Eu} . \mathrm{L}^{1}\right]^{3+}\left(50 \mu \mathrm{M}, \lambda_{\mathrm{exc}} 355 \mathrm{~nm}\right)$. Each row is a set of images from a time-series taken $15 \mathrm{sec}$ apart, following a $30 \mathrm{~min}$. incubation with each dye. The column in red shows Eu emission $(605-720 \mathrm{~nm})$; the central images show MitoTracker staining in green $\left(\lambda_{\mathrm{exc}} 488 \mathrm{~nm}, \lambda_{\mathrm{em}} 505-550 \mathrm{~nm}\right)$, with the colocalisation of the two dyes in yellow on the right $(\mathrm{P}>0.85)$. Through these time-points, the small mobile mitochondria can be seen (e.g. on the left hand side) streaming through the cytoplasm, from right to left (ESI: a movie based in part on this data is available to view).
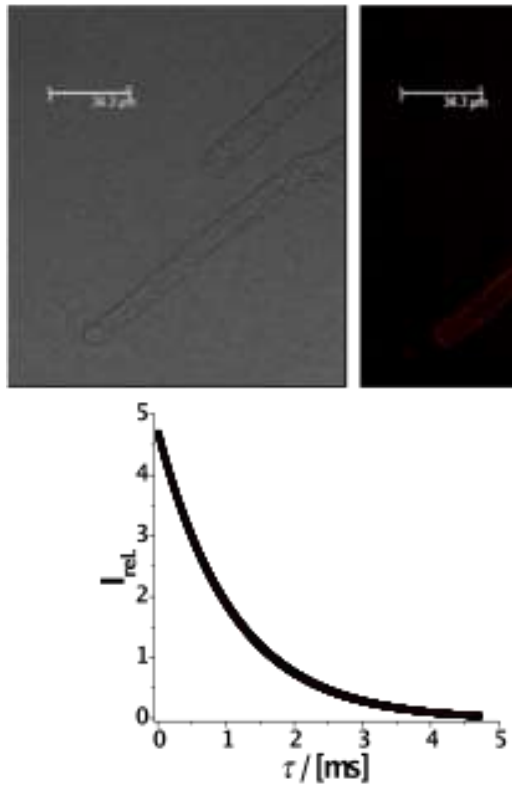
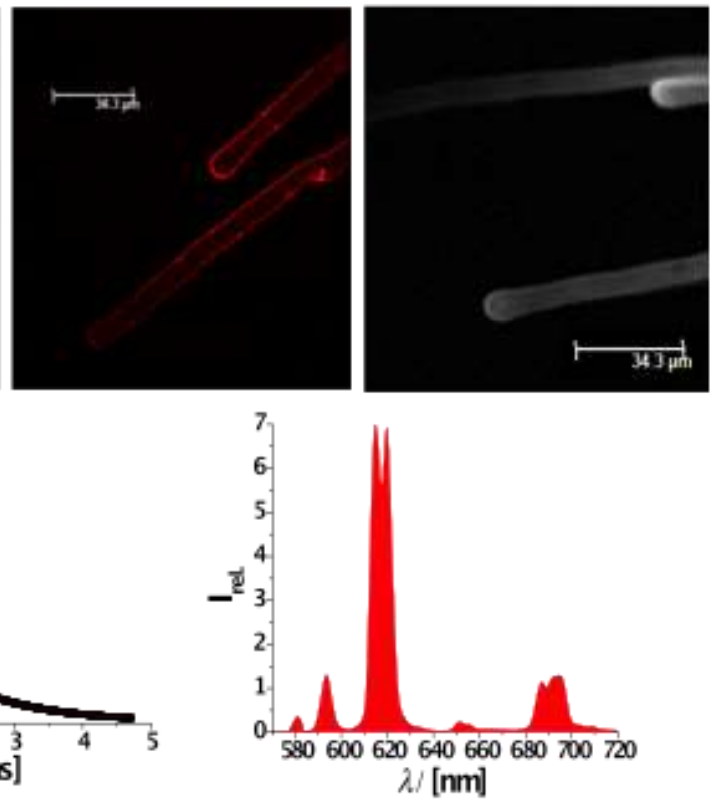

Figure 5 Upper: transmission (left) and laser scanning confocal microscopy (centre) $\left(\lambda_{\text {exc }} 355 \mathrm{~nm} ; \lambda_{\text {em }} 605-720 \mathrm{~nm}, 100 \mathrm{~Hz}, 4\right.$ avg. 1024 x 1024, voxel size 120 x 120 x $790 \mathrm{~nm}$ ), time-gated epifluorescence image of proximate root hairs (right) $\left(\lambda_{\mathrm{exc}} 365 / 10 \mathrm{~nm} ; \lambda_{\mathrm{em}} \mathrm{LP} 570\right.$ $\mathrm{nm} ; \mathrm{t}_{\mathrm{g}} 10 \mu \mathrm{s}, \mathrm{t}_{\mathrm{acq}} 5 \mathrm{~ms}, 100$ acq. image), of Nicotiana tabacum roots following incubation with [Eu.L $\left.{ }^{4}\right]^{-}(10 \mu \mathrm{M}, 2 \mathrm{~h})$, showing the external cell wall staining; lower: lifetime decay ( $\tau_{\mathrm{Eu}} 1.10$ $\left.\mathrm{ms}, \lambda_{\varepsilon x c} 365 \mathrm{~nm} ; \lambda_{\mathrm{em}} 620 / 20 \mathrm{~nm}\right)$ and time-gated emission spectrum $\left(\lambda_{\mathrm{exc}} 365 \mathrm{~nm} ; \mathrm{t}_{\mathrm{g}} 10 \mu \mathrm{s}, \mathrm{t}_{\mathrm{acq}}\right.$ $1 \mathrm{~ms}, 1000 \mathrm{avg}$. cycle) showing the profile typical of the intact complex. 
Pollen tubes are fast growing tissues that are very delicate and susceptible to bursting if their external environment is perturbed. Pollen from Nicotiana tabacum was germinated and held at $21{ }^{\circ} \mathrm{C}$ for $2 \mathrm{~h}$. At this point, the medium was changed to that containing $\left[\mathrm{Eu} . \mathrm{L}^{1}\right]^{3+}(100 \mathrm{mM})$ and returned to $21^{\circ} \mathrm{C}$ for a further hour. Using 405 $\mathrm{nm}$ excitation (30\% power), the membrane of the pollen tubes was stained (Figure 6), but the pollen tubes almost immediately burst and discharged their contents from the tip, often before an image could be captured. Blank controls without the Eu complex did not burst, after irradiation for at least 150 seconds with the $405 \mathrm{~nm}$ laser at the same $10 \mathrm{~mW}$ power $(<250 \mathrm{~nJ} /$ voxel). The laser power was reduced to $5 \%$ but pollen tubes usually exploded too quickly for a clear image to be obtained. It was noted that using other wavelengths of laser irradiation (488 or $532 \mathrm{~nm}$ ) or under white light illumination, the pollen tubes did not discharge. Fixed pollen tubes showed no uptake of the complex, and tubes incubated with the other two Eu complexes containing the azathiaxanthone chromophore did not stain the tube at all.

A further systematic series of experiments was undertaken with $\left[\mathrm{Eu} . \mathrm{L}^{1}\right]^{3+}$ in order to assess its ability to stain these tubes. Varying concentrations of the europium complex were used (10 to $100 \mathrm{mM}$ ), and the incubation time and laser power ( $\lambda_{\mathrm{exc}} 405$ $\mathrm{nm} ; 1$ to $30 \%$ ) were also changed. Typically, the concentration of $\left[\mathrm{Eu} . \mathrm{L}^{1}\right]^{3+}$ was 50 or $100 \mu \mathrm{M}$, the incubation time was between 1 and 3 hours and the laser power varied between 8 and $30 \%$. Operating within these limits did not appear to affect the likelihood of a pollen tube bursting, when excited with the $405 \mathrm{~nm}$ laser.

Out of over 40 pollen tubes for which time lapsed images were captured, $81 \%$ of those incubated had burst within 3-10 frames (4 image average) (i.e. 30 - 100 seconds of excitation). Usually when the tubes burst, the force of the ejecting cytoplasm moved them out of focus or field of view, but some sequences were captured that allowed the process to be followed (Figure 6). It was also observed that longer tubes were more likely to burst than shorter ones. This was true both within this series of experiments and as a general comparison, between longer and shorter tubes that had not been exposed to laser excitation. Comparing tubes that burst under the same power of laser excitation, longer tubes burst in a shorter time, i.e. required less excitation than the shorter tubes.

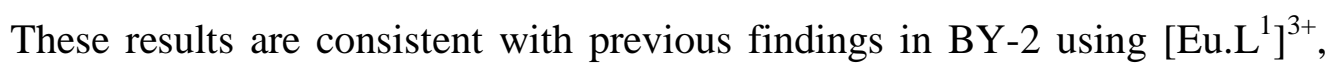
whereby excitation with $405 \mathrm{~nm}$ also was observed to lead to cell death over repeated 
imaging, while excitation at longer wavelengths or in the absence of complex did not. There are a number of mechanisms that could explain this behaviour, a priori, but the most likely explanation relates to a photochemical reaction of the excited chromophore of the Eu complex when it is localised in the membrane. The triplet excited state of the azathiaxanthone is known to possess $n-\pi^{*}$ character, and hydrogen atom abstraction reactions have been reported in protic media with the parent system following excitation. $^{29}$
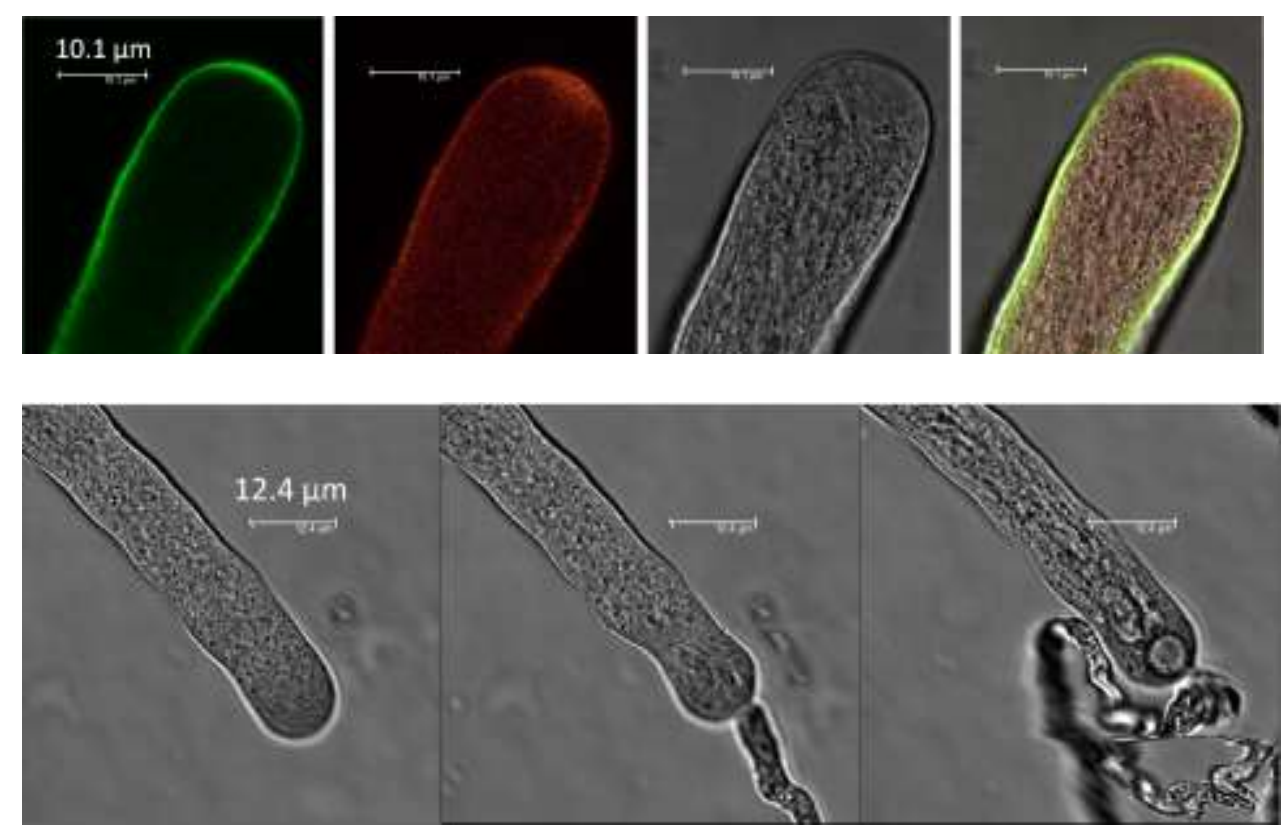

Figure 6 Upper: Images of a Nicotiana tabacum pollen tube tip immediately following incubation with [Eu.L $\mathrm{L}^{1}$ ] $\left(30 \mathrm{~min}, 50 \mathrm{mM} ; \lambda_{\mathrm{exc}} 405 \mathrm{~nm}\right)$; showing: left, fluorescence from the azathiaxanthone chromophore (435 - $565 \mathrm{~nm})$; left centre: Eu emission $(570$ - $720 \mathrm{~nm})$; right centre: brightfield image; right: overlay of the three images; lower: sequential microscopy images taken at 10 second intervals showing the bursting of a pollen tube at its tip, following incubation with [Eu.L $\left.{ }^{1}\right](3 \mathrm{~h}, 50 \mathrm{mM})$ and $30-50$ seconds after excitation with $405 \mathrm{~nm}$ light (10\% laser power, $3.5 \mathrm{~mW}, 100 \mathrm{~nJ} /$ voxel).

Such a hydrogen atom abstraction from water would generate a reactive hydroxyl radical that could abstract a hydrogen atom from an $\mathrm{OH}$ or $\mathrm{CH}$ group in the cellulose/pectins or glycoproteins that make up the cell wall, initiating a fast radical chain oxidation process that leads to an irreversible change in the stability and permeability of the cell wall. Longer tubes could be more likely to burst because they are closer to the length to which they would usually grow before reaching the synergid cells; signals which cause the release of sperm cells may be building up, ready to be triggered by the synergid cells or their environment. It could be that pressure of the cytoplasm on the membrane increases as the tube gets longer to keep 
growth going, making the tubes more likely to burst.

Pollen tubes that are not growing, e.g. those that are fixed, rarely burst. This can be explained, as pollen tube growth emanates from the tip; this is also the point at which they burst and release their cytoplasm. Membrane and cell wall material is delivered to the tube tip by vesicles via 'reverse fountain' cytoplasmic streaming followed by exocytosis. With vesicles fusing to the cell membrane at the tip of a growing tube, this area of the membrane is weaker and so may be more susceptible to bursting. In tubes that are not growing, vesicle fusion is less frequent, so the membrane here is as strong as in the rest of the tube. Tubes bursting from points other than the tip were not observed, indicating that the usual strength of the membrane is sufficient to resist the effects caused by the presence of the excited europium complex.

\section{Conclusions and summary}

The development of optical probes that function well for the analysis of cells in plant cells, cultures and mature tissues, is less well developed than in the animal or fungal kingdoms. Here, we have examined the scope and utility of a small set of emissive europium complexes in three different plant systems. The azathiaxanthone complex, [Eu.L $\left.{ }^{1}\right]^{3+}$, that can be excited at $405 \mathrm{~nm}$, was found to be a useful general stain for cell walls in BY-2 cells, leaves and in plant root hairs. Indeed, it also serves as a means of distinguishing dying, plasmolysed or dead cells with compromised permeability. In roots, it could also be used to visualize the tumbling of mitochondria in the living root, in real time. The combined use of time-gated microscopy and spectral imaging was exemplified in the same system with the bright complex, [Eu.L $\left.{ }^{4}\right]^{-}$.

Finally, an unusual means of triggering pollen tube discharge has been identified, that requires prior localization of a Eu complex bearing an azathiaxanthone chromophore. Bursting at the pollen tip was triggered selectively by excitation with $405 \mathrm{~nm}$ light, allowing controlled pollen release processes to be contemplated. A similar photochemical reaction may also explain the permeabilisation of the BY-2 cell wall, following prolonged excitation in the presence of this particular complex.

\section{Experimental}




\section{Europium complexes}

The synthesis of the complexes $\left[E u . L^{n}\right](n=1,3,4,5)$ has been described earlier $21,23,24$ together with details of general instrumentation and chemical methods of analysis.

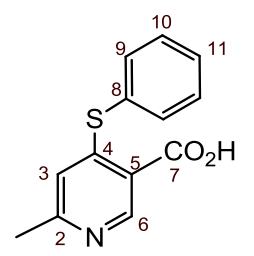

\section{4-Thiophenoxy-6-methylnicotinic acid}

4-Chloro-6-methylnicotinic acid, (4.6 g, $27 \mathrm{mmol})$ and thiophenol (3.6 g, $33 \mathrm{mmol})$ were dissolved in dimethylformamide $(50 \mathrm{~mL})$. $\mathrm{CuBr}(250 \mathrm{mg}, 1.7 \mathrm{mmol})$ and $\mathrm{K}_{2} \mathrm{CO}_{3}$ (5.4 g, $40 \mathrm{mmol}$ ) were added and the mixture was stirred at $150{ }^{\circ} \mathrm{C}$ for $16 \mathrm{~h}$ under argon. After allowing the brown solution to cool to $23{ }^{\circ} \mathrm{C}, \mathrm{H}_{2} \mathrm{O}(150 \mathrm{~mL})$ was added and excess thiophenol was extracted with $\mathrm{Et}_{2} \mathrm{O}(3 \times 50 \mathrm{~mL})$. The $\mathrm{pH}$ was reduced to 4.6 by the addition of $\mathrm{AcOH}$. Upon stirring at $0{ }^{\circ} \mathrm{C}$ a pale brown precipitate formed which was collected by filtration and washed with cold ether to give a pale yellow solid $(1.8$ g, $27 \%)$; m.p. $142-144^{\circ} \mathrm{C}, \delta_{\mathrm{H}}\left(\mathrm{CDCl}_{3}\right) 8.82\left(1 \mathrm{H}, \mathrm{s}, \mathrm{H}^{6}\right), 7.58\left(5 \mathrm{H}, \mathrm{m}, \mathrm{H}^{8,9}\right.$, $\left.{ }^{10,11}\right), 6.52\left(1 \mathrm{H}, \mathrm{s}, \mathrm{H}^{3}\right), 2.29\left(3 \mathrm{H}, \mathrm{s}, \mathrm{CH}_{3}\right) ; \delta_{\mathrm{C}}\left(\mathrm{CDCl}_{3}\right) 166.8\left(\mathrm{C}^{7}\right), 160.0\left(\mathrm{C}^{4}\right), 156.9$ $\left(C^{5}\right), 154.7\left(C^{6}\right), 149.6\left(C^{8}\right), 135.7\left(C^{3}\right), 130.0\left(C^{2}\right), 129.2\left(C^{9}\right), 119.5\left(C^{10}\right), 109.2$ $\left(\mathrm{C}^{11}\right), 22.0\left(\mathrm{C}^{1}\right), \mathrm{m} / \mathrm{z}\left(\mathrm{HRMS}^{-}\right) 244.0436[\mathrm{M}-\mathrm{H}]^{-}\left(\mathrm{C}_{13} \mathrm{H}_{10} \mathrm{O}_{2} \mathrm{NS}\right.$ requires 244.0438).

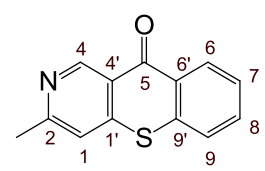

\section{2-Methyl-3-azathiaxanthone}

4-Thiophenoxy-6-methylnicotinic acid, (1.80 g, $7.35 \mathrm{mmol})$ and polyphosphoric acid $(50 \mathrm{~g})$ were heated to $120^{\circ} \mathrm{C}$ for $16 \mathrm{~h}$ under argon. The resulting brown solution was cooled to room temperature and poured into ice $(250 \mathrm{~g})$. The $\mathrm{pH}$ of the yellow solution was adjusted to 7 by addition of $\mathrm{KOH}$ pellets. The aqueous solution was then extracted with $\mathrm{CHCl}_{3}(3 \times 100 \mathrm{~mL})$. The organic layers were combined, dried over $\mathrm{MgSO}_{4}$, filtered and the solvent was removed under reduced pressure to give a brown solid, which was purified by column chromatography on silica $\left(\mathrm{CH}_{2} \mathrm{Cl}_{2}: 0-5 \%\right.$ 
$\mathrm{MeOH}$ in $0.5 \%$ increments) to yield a pale yellow solid (1.00 g, $60 \%$ ), m.p. 174 $176^{\circ} \mathrm{C}, \delta_{\mathrm{H}}\left(\mathrm{CDCl}_{3}\right) 9.54\left(1 \mathrm{H}, \mathrm{s}, \mathrm{H}^{4}\right), 8.56\left(1 \mathrm{H}, \mathrm{d}, J 8.4 \mathrm{~Hz}, \mathrm{H}^{6}\right), 7.61(1 \mathrm{H}, \mathrm{dd}, J 7.0$ $\left.\mathrm{Hz}, 8.4 \mathrm{~Hz}, \mathrm{H}^{8}\right), 7.52\left(1 \mathrm{H}, \mathrm{d}, J 8.4 \mathrm{~Hz}, \mathrm{H}^{9}\right), 7.49\left(1 \mathrm{H}, \mathrm{dd}, J 7.0 \mathrm{~Hz}, 8.4 \mathrm{~Hz}, \mathrm{H}^{7}\right), 7.25$ $\left(1 \mathrm{H}, \mathrm{s}, \mathrm{H}^{1}\right), 2.62\left(3 \mathrm{H}, \mathrm{s}, \mathrm{CH}_{3}\right) ; \delta_{\mathrm{C}}\left(\mathrm{CDCl}_{3}\right) 179.2\left(\mathrm{C}^{5}\right), 160.3\left(\mathrm{C}^{2}\right), 151.8\left(\mathrm{C}^{4}\right), 146.8$ $\left(C^{4}\right), 136.0\left(C^{9}\right), 132.4\left(C^{8}\right), 130.5\left(C^{6}\right), 129.7\left(C^{6}\right), 127.2\left(C^{7}\right), 126.2\left(C^{9}\right), 121.9$ $\left(\mathrm{C}^{1}\right), 118.5\left(\mathrm{C}^{1}\right), 24.6\left(\mathrm{CH}_{3}\right), \mathrm{m} / z\left(\mathrm{HRMS}^{+}\right) 228.0402[\mathrm{M}+\mathrm{H}]^{+}\left(\mathrm{C}_{13} \mathrm{H}_{10} \mathrm{ONS}\right.$ requires 228.0405 ); $R_{f}=0.46$ (silica, $\mathrm{CH}_{2} \mathrm{Cl}_{2}: 2.5 \% \mathrm{MeOH}$ ).

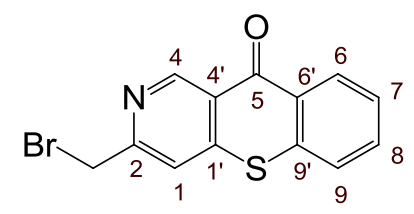

\section{2-Bromomethyl-3-azathiaxanthone}

To a solution of 2-methyl-3-azathiaxanthone (500 $\mathrm{mg}, 2.20 \mathrm{mmol})$ in carbon tetrachloride $(40 \mathrm{~mL})$ was added N-bromo-succinimde $(376 \mathrm{mg}, 2.20 \mathrm{mmol})$ and dibenzoyl peroxide $(20 \mathrm{mg}, 0.08 \mathrm{mmol}$ ). The mixture was stirred and irradiated by a $100 \mathrm{~W}$ lamp under argon. The reaction was monitored by ${ }^{1} \mathrm{H}-\mathrm{NMR}$ and stopped after $14 \mathrm{~h}$. The solvent was removed under reduced pressure and the crude product was dissolved in $\mathrm{CH}_{2} \mathrm{Cl}_{2}(30 \mathrm{~mL})$ and washed with dilute $\mathrm{K}_{2} \mathrm{CO}_{3}$ solution $(30 \mathrm{~mL})$ to remove excess succinimide. The organic layer was dried over $\mathrm{MgSO}_{4}$, filtered and the solvent removed under reduced pressure. Purification by column chromatography on silica (petroleum ether $\left(60-80{ }^{\circ} \mathrm{C} \mathrm{bp}\right): 0-10 \%$ EtOAc in $1 \%$ increments) yielded a pale yellow solid $(160 \mathrm{mg}, 24 \%)$, m.p. $189-192{ }^{\circ} \mathrm{C}, \delta_{\mathrm{H}}\left(\mathrm{CDCl}_{3}\right) 9.59\left(1 \mathrm{H}, \mathrm{s}, \mathrm{H}^{4}\right)$, $8.58\left(1 \mathrm{H}, \mathrm{d}, J 8.5 \mathrm{~Hz}, \mathrm{H}^{6}\right), 7.66\left(1 \mathrm{H}, \mathrm{dd}, J 7.0 \mathrm{~Hz}, 8.5 \mathrm{~Hz}, \mathrm{H}^{8}\right), 7.57\left(1 \mathrm{H}, \mathrm{s}, \mathrm{H}^{1}\right), 7.55$ $\left(1 \mathrm{H}, \mathrm{d}, J 8.5 \mathrm{~Hz}, \mathrm{H}^{9}\right), 7.54\left(1 \mathrm{H}, \mathrm{dd}, J 7.0 \mathrm{~Hz}, 8.4 \mathrm{~Hz}, \mathrm{H}^{7}\right), 4.60\left(2 \mathrm{H}, \mathrm{s}, \mathrm{CH}_{2} \mathrm{Br}\right) ; \delta_{\mathrm{C}}$ $\left(\mathrm{CDCl}_{3}\right) 178.8\left(\mathrm{C}^{5}\right), 157.8\left(\mathrm{C}^{2}\right), 152.1\left(\mathrm{C}^{4}\right), 147.7\left(\mathrm{C}^{4}\right), 135.7\left(\mathrm{C}^{9}\right), 133.2\left(\mathrm{C}^{8}\right), 129.7$ $\left(\mathrm{C}^{6}\right), 128.4\left(\mathrm{C}^{6^{\prime}}\right), 127.4\left(\mathrm{C}^{7}\right), 126.3\left(\mathrm{C}^{9}\right), 123.1\left(\mathrm{C}^{1}\right), 119.2\left(\mathrm{C}^{1}\right), 32.6\left(\mathrm{CH}_{2} \mathrm{Br}\right), \mathrm{m} / \mathrm{z}$ $\left(\mathrm{HRMS}^{+}\right) 305.9513[\mathrm{M}+\mathrm{H}]^{+}\left(\mathrm{C}_{13} \mathrm{H}_{9} \mathrm{ONS}{ }^{79} \mathrm{Br}\right.$ requires 305.9508$) ; R_{f}=0.58$ (silica, $\mathrm{CH}_{2} \mathrm{Cl}_{2}: \mathrm{MeOH} 2 \%$ ).

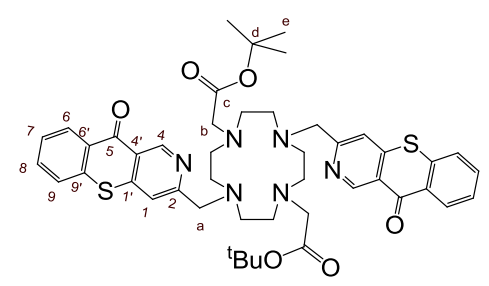




\section{1,7-Bis(tert-butoxycarbonyl)-4,10-bis[2-methyl-3-azathiaxanthone]-1,4,7,10- tetraazacyclododecane}

1,7-Bis(tert-butoxycarbonyl)-1,4,7,10-tetraazacyclododecane (49 mg, $0.12 \mathrm{mmol}$ ), 2bromomethyl-3-azathiaxanthone, ${ }^{22}$ (106 mg, $0.35 \mathrm{mmol}$ ) and $\mathrm{K}_{2} \mathrm{CO}_{3}(35 \mathrm{mg}, 0.34$ mmol) were stirred in dry $\mathrm{CH}_{3} \mathrm{CN}(4 \mathrm{~mL})$ at $78{ }^{\circ} \mathrm{C}$ for $18 \mathrm{~h}$ under argon. The reaction was monitored by TLC to confirm that the brominated starting material had been consumed. The solvent was removed under reduced pressure and the residue dissolved in $\mathrm{CH}_{2} \mathrm{Cl}_{2}(25 \mathrm{~mL})$ and extracted with water $(3 \times 25 \mathrm{~mL})$. The organic layer was dried over $\mathrm{MgSO}_{4}$, filtered and solvent removed under reduced pressure. The yellow residue was purified by column chromatography on silica $\left(\mathrm{CH}_{2} \mathrm{Cl}_{2}: 5 \%\right.$ $\mathrm{MeOH})$ to give the title compound as a glassy yellow solid (70 mg, $68 \%$ ); $\delta_{\mathrm{H}}$ $\left(\mathrm{CDCl}_{3}\right) 9.42\left(2 \mathrm{H}, \mathrm{s}, \mathrm{H}^{4}\right), 8.55\left(2 \mathrm{H}, \mathrm{d}, J 8.5 \mathrm{~Hz}, \mathrm{H}^{6}\right), 7.67(2 \mathrm{H}, \mathrm{dd}, J 7.0 \mathrm{~Hz}, 8.5 \mathrm{~Hz}$, $\left.\mathrm{H}^{8}\right), 7.60\left(2 \mathrm{H}, \mathrm{dd}, J 7.0 \mathrm{~Hz}, 8.4 \mathrm{~Hz}, \mathrm{H}^{7}\right), 7.51\left(2 \mathrm{H}, \mathrm{d}, J 8.5 \mathrm{~Hz}, \mathrm{H}^{9}\right), 7.48\left(2 \mathrm{H}, \mathrm{s}, \mathrm{H}^{1}\right)$, $3.51\left(4 \mathrm{H}\right.$, br s, $\left.\mathrm{H}^{\mathrm{a}}\right), 3.25\left(4 \mathrm{H}, \mathrm{s}, \mathrm{H}^{\mathrm{b}}\right), 3.00-2.40(16 \mathrm{H}$, br m, cyclen $\mathrm{Hs}), 1.38(18 \mathrm{H}, \mathrm{s}$, $\left.\mathrm{H}^{\mathrm{e}}\right), \delta_{\mathrm{C}}\left(\mathrm{CDCl}_{3}\right) 178.8\left(\mathrm{C}^{5}\right), 172.5\left(\mathrm{C}^{\mathrm{c}}\right) 160.1\left(\mathrm{C}^{2}\right), 151.8\left(\mathrm{C}^{4}\right), 147.4\left(\mathrm{C}^{4}\right), 135.6\left(\mathrm{C}^{9}\right)$, $133.2\left(C^{8}\right), 130.2\left(C^{6}\right), 129.7\left(C^{6}\right), 127.3\left(C^{7}\right), 126.4\left(C^{9}\right), 123.1\left(C^{1}\right), 119.3\left(C^{1}\right)$, $82.7\left(\mathrm{C}^{\mathrm{d}}\right), 58.6\left(\mathrm{C}^{\mathrm{b}}\right), 57.2\left(\mathrm{C}^{\mathrm{a}}\right), 51.0-49.0$ (cyclen Cs), $28.1\left(\mathrm{C}^{\mathrm{e}}\right), \mathrm{m} / \mathrm{z}\left(\mathrm{HRMS}^{+}\right)$ $851.3629[\mathrm{M}+\mathrm{H}]^{+}\left(\mathrm{C}_{46} \mathrm{H}_{55} \mathrm{O}_{6} \mathrm{~N}_{6} \mathrm{~S}_{2}\right.$ requires 851.3624); $R_{f}=0.58$ (silica, $\mathrm{CH}_{2} \mathrm{Cl}_{2}$ : $\mathrm{MeOH} 2 \%)$.

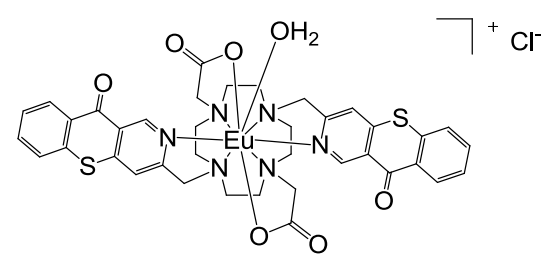

Europium(III) chloride complex of 1,7-bis(acetic acid)-4,10-bis[2-methyl-3azathiaxanthone]-1,4,7,10-tetraazacyclododecane, $\left[\mathrm{Eu} \cdot \mathrm{L}^{2 b}\right] \mathrm{Cl}$

1,7-Bis(tert-butoxycarbonyl)-4,10-bis[2-methyl-3-azathiaxanthone]-1,4,7,10tetraazacyclododecane $(41 \mathrm{mg}, 0.048 \mathrm{mmol})$ was dissolved in $\mathrm{CH}_{2} \mathrm{Cl}_{2}(2 \mathrm{~mL})$ and $\mathrm{CF}_{3} \mathrm{CO}_{2} \mathrm{H}(2 \mathrm{~mL})$ was added. The mixture was stirred at $22{ }^{\circ} \mathrm{C}$ under argon for $16 \mathrm{~h}$. Excess $\mathrm{CF}_{3} \mathrm{CO}_{2} \mathrm{H}$ and $\mathrm{CH}_{2} \mathrm{Cl}_{2}$ were removed under reduced pressure and the yellow residue was redissolved in $\mathrm{CH}_{2} \mathrm{Cl}_{2}$. The solvent was again removed under reduced pressure to ensure the removal of all $\mathrm{CF}_{3} \mathrm{CO}_{2} \mathrm{H}$. Deprotection of the $\mathrm{O}^{t} \mathrm{Bu}$ groups was confirmed by ${ }^{1} \mathrm{H}-\mathrm{NMR}$ before the residue was dissolved in $\mathrm{H}_{2} \mathrm{O}-\mathrm{CH}_{3} \mathrm{OH}(4: 1 \mathrm{v} / \mathrm{v}$, 
$4 \mathrm{~mL})$. Addition of $\mathrm{Eu}(\mathrm{OAc})_{3}(23 \mathrm{mg}, 0.058 \mathrm{mmol})$ was followed by adjustment of the $\mathrm{pH}$ to 5.8, by the addition of aq. ammonia solution, and the mixture was stirred at $60{ }^{\circ} \mathrm{C}$ for $18 \mathrm{~h}$. After allowing the solution to cool to room temperature, the $\mathrm{pH}$ was raised to 10 by the addition of aq. ammonia solution. The solution was stirred for $1 \mathrm{~h}$ causing excess $\mathrm{Eu}^{3+}$ to precipitate as $\mathrm{Eu}(\mathrm{OH})_{3}$, which was removed by syringe filtration. Adjustment of the $\mathrm{pH}$ to 5.8 by the addition of $\mathrm{CH}_{3} \mathrm{CO}_{2} \mathrm{H}$, followed by lyophilisation of the solvent, gave the product as the acetate salt. The solid was converted to the chloride salt by stirring in $\mathrm{H}_{2} \mathrm{O}$ for $1 \mathrm{~h}$ with Dowex $1 \times 8$ 200-400 mesh $\mathrm{Cl}^{-}$, which had been washed with $1 \mathrm{M} \mathrm{HCl}$ and neutralised with water. The Dowex resin was removed by filtration and the solvent lyophilised to yield the title compound as a yellow solid $(20 \mathrm{mg}, 47 \%), \mathrm{m} / z\left(\mathrm{HRMS}^{+}\right) 887.1329[\mathrm{M}-\mathrm{Cl}]^{+}$ $\left(\mathrm{C}_{38} \mathrm{H}_{36} \mathrm{O}_{6} \mathrm{~N}_{6} \mathrm{~S}_{2}{ }^{151} \mathrm{Eu}\right.$ requires 887.1336); $\tau\left(\mathrm{D}_{2} \mathrm{O}\right)=0.56 \mathrm{~ms}, \tau\left(\mathrm{D}_{2} \mathrm{O}\right)=1.57 \mathrm{~ms}, \phi_{\mathrm{em}}$ (water) $8.3 \% ; t_{R}=6.4 \mathrm{~min}$.

\section{HPLC analyses}

Reverse phase HPLC analysis was performed at $298 \mathrm{~K}$ on a Perkin Elmer system, comprising a Perkin Elmer Series 200 pump, Perkin Elmer Series 200 autosampler, Perkin Elmer Series 200 UV/Vis detector and Perkin Elmer Series 200 fluorescence detector. Either a $150 \times 4.66 \mathrm{~mm} 4$ micron Phenomenex Synergi $4 \mu$ Fusion-RP 80i column or an XBridge C-18 $10 \mathrm{~cm}$ x $3.5 \mu \mathrm{m}$ column was used with a flow rate of 1 $\mathrm{mL} / \mathrm{min}$ and run times varying from $15-25 \mathrm{~min}$. A solvent system of $\mathrm{H}_{2} \mathrm{O}(0.1 \%$ $\mathrm{HCOOH}) / \mathrm{CH}_{3} \mathrm{CN}(0.1 \% \mathrm{HCOOH})$ (gradient elution) was used. The UV/Vis and fluorescence detectors were set at $340 \mathrm{~nm}$ and $615 \mathrm{~nm}$ respectively.

\section{Plant materials}

The following tobacco $B Y-2$ cell lines were grown in the dark at $25^{\circ} \mathrm{C}$ with shaking in BY-2 medium: wild type lines BY2-1, BY2-2 and BY2-JI, along with cell lines expressing GFP-TDP6, RFP-TDP6, GFP-Lifeact. The lanthanide complexes were added to the culture medium immediately before imaging at a final concentration of $100 \mu \mathrm{M}$. Control experiments were undertaken on cells with no dyes added to rule out autofluorescence. The BY-2 growth medium contains 4.4g/L Murashige and Skoog medium with $10 \mathrm{ml} / \mathrm{L}$ Kao \& Michayluk vitamins, $250 \mathrm{mg} / \mathrm{L}$ sucrose, $68.4 \mathrm{~g} / \mathrm{L}$ of glucose, $0.2 \mathrm{mg} / \mathrm{L} \mathrm{2,4-} \mathrm{dichlorophenoxyacetic} \mathrm{acid,} 0.5 \mathrm{mg} / \mathrm{L}$ zeatine, $1 \mathrm{mg} / \mathrm{L} \mathrm{NAA}$ at $\mathrm{pH}$ 5.6. In order to isolate protoplasts from $B Y-2$ cells, $500 \mathrm{mg}$ cellulase, $100 \mathrm{mg}$ pectinase, $0.037 \mathrm{~g} \mathrm{CaCl}_{2} .2 \mathrm{H}_{2} \mathrm{O}, 75 \mathrm{mg} \mathrm{KCl}, 200 \mathrm{mg}$ and $12 \mathrm{~g}$ sucrose were dissolved 
in $50 \mathrm{ml} \mathrm{H}_{2} \mathrm{O}$ and the $\mathrm{pH}$ was adjusted to 5.7 before filter sterilisation. The cells were left in this solution at room temperature overnight, before being centrifuged and then re-suspended in growth medium before dye incubation and imaging.

For the leaf experiments, Nicotiana benthamiana plants were grown in soil. Once the leaves were grown to approximately $3 \mathrm{~cm}$ in diameter leaf infiltration was undertaken using a $1 \mathrm{ml}$ syringe filled with a $100 \mu \mathrm{M}$ solution of the complex, followed by imaging. Control experiments were undertaken where water was used to infiltrate the leaves, to rule out autofluorescence or emission caused by the infiltration procedure. For the root studies, Columbia wild type Arabidopsis thaliana seeds were sterilized in $1 \%$ bleach for $10 \mathrm{~min}$., washed twice in sterile water, and planted on either a) "1/2MS10" half-strength Murashige and Skoog basal salt medium supplemented with $1 \%$ sucrose and $0.8 \%$ agar or $b$ ) " $1 / 2 \mathrm{MS}$ " half-strength Murashige and Skoog basal salt medium supplemented with $0.8 \%$ agar, both at $\mathrm{pH} 5.7$. The plates were vernalized for 2 days at $4{ }^{\circ} \mathrm{C}$, then grown in a growth cabinet at $21^{\circ} \mathrm{C}$. At 5-14 days, seedlings were incubated with $100 \mu \mathrm{M}$ of the relevant compounds and used for imaging. It was found that the seeds on " $1 / 2 \mathrm{MS} 10$ " plates grew faster but were otherwise indistinguishable from those grown on " $1 / 2 \mathrm{MS}$ ". Control experiments were undertaken using roots incubated with $\mathrm{H} 2 \mathrm{O}$ only to understand the level of autofluorescence and fluorescence caused by the experimental procedure. For roots grown in liquid medium the following medium was used: $0.5 \mathrm{~g} / \mathrm{L}$ MES, $0.1 \mathrm{~g} / \mathrm{L}$ myoinositol, $10.0 \mathrm{~g} / \mathrm{L}$ sucrose, $0.303 \mathrm{~g} / \mathrm{L} \quad \mathrm{KNO}_{3}, 0.472 \mathrm{~g} / \mathrm{L} \mathrm{Ca}\left(\mathrm{NO}_{3}\right)_{2}, 0.123 \mathrm{~g} / \mathrm{L}$ $\mathrm{MgSO}_{4} .7 \mathrm{H}_{2} \mathrm{O}, 0.115 \mathrm{~g} / \mathrm{L}\left(\mathrm{NH}_{4}\right)_{2} \mathrm{HPO}_{4}, 1 \mathrm{mg} / \mathrm{L}$ thiamine, $0.5 \mathrm{mg} / \mathrm{L}$ pyridoxine- $\mathrm{HCl}$, $0.5 \mathrm{mg} / \mathrm{L}$ nicotinic acid, with a $0.1 \%$ micronutrient mix. The seeds were placed upon a microscope slide with an attached cover slip filled with medium, held at an angle and their roots allowed to grow down into the gap between the slide and the cover slip. The dyes were added under the cover slip before imaging.

\section{Microscopy}

Cells from liquid cultures were pipetted into $32 \mathrm{~mm}$ diameter Petri dishes with $22 \mathrm{~mm}$ diameter glass cover-slips in the bottom. Roots and leaves were placed upon glass microscope slides and covered with a glass cover-slip. Confocal microscopy images were acquired using a pair of Leica SP5 II laser scanning confocal microscopy systems, equipped with a variable temperature control unit to maintain the constant temperature required for the relevant experiment. The lanthanide complexes were 
excited using either a $405 \mathrm{~nm}$ diode laser or a $355 \mathrm{~nm}$ NdYAG 3rd harmonic laser at $30 \%$ power $(12 \mathrm{~mW})$. Emitted light was collected between $605-720 \mathrm{~nm}$ utilising the HyD detector on the Leica SP5, or between 600-720 nm on one of the PMTs (photomultiplier tubes) to look at the lanthanide emission. Images were also recorded between 410-500 $\mathrm{nm}$ to look at the organic emission when required. GFP and green probes were excited using the $488 \mathrm{~nm}$ line of an argon laser between 15-20\% power (6-10 $\mathrm{mW})$. For these experiments on the Leica system emitted light was collected between 500-590 $\mathrm{nm}$ and on the Zeiss system emitted light was collected using a long pass $505 \mathrm{~nm}$ filter. MitoTracker Orange was excited using the $488 \mathrm{~nm}$ line of an argon laser at $30 \%$ power and emitted light was collected between 550-700 nm on the Leica system, whereas on the Zeiss system a long pass $560 \mathrm{~nm}$ filter was used.

For all images either a 40x/1.3 Plan Apo UV oil immersion or a $\lambda$ Blue 63x/1.4 plan UV oil immersion objective lens was used. Gain, digital offset line average and speed values were optimised in each experiment. The control experiments were undertaken with the same laser power and gain settings to ensure that no autofluorescence was visible. For multi-colour imaging, the channels were acquired sequentially. The images were exported in TIFF format, and figures were assembled using ImageJ 1.47 and Inkscape 0.48 software.

\section{Spectral imaging}

Spectral imaging in cells was achieved using a custom built microscope (modified Zeiss Axiovert 200M), using a Zeiss APOCHROMAT 63x/1.40 NA oil objective combined with a low voltage $365 \mathrm{~nm}$ pulsed UV LED focused, collimated excitation source $(1.2 \mathrm{~W}$, ca. $1200 \mathrm{~nJ} / \mu \mathrm{m} 2 \mathrm{~s})$. For rapid spectral acquisition the microscope was equipped at the external port with a Peltier cooled 2D-CCD detector (Ocean Optics) used in an inverse $100 \mathrm{~Hz}$ time gated sequence. The spectrum was recorded from 400$800 \mathrm{~nm}$ with a resolution of $0.24 \mathrm{~nm}$ and the final spectrum was acquired using an averaged 10,000 scan duty cycle. Probe lifetimes were measured on the same microscope platform using a novel emission decay profiling sequence cooled PMT detector (Hamamatsu H7155) interchangeable on the external port, with the application of preselected interference filters. Both the control and detection algorithm were written in LabView2011. The probe lifetime was determined by using a single exponential fitting algorithm to the monitored signal intensity decay. Time gated imaging was achieved using the same $10 \mathrm{~Hz}$ sequence (50-200 summed duty 
cycle)as for spectral acquisition, using a gated and cooled high resolution ThorLabs EOS Monochrome mCCD camera.

Acknowledgements We thank the ERC (FCC 266804: SJB, DP, RP), CISbio (JWW) and Durham University for support, and Dr Chris Ottley (Geology) for the ICP-MS measurements.

\section{References}

1. J. Kronenberger, T. Desprez, H. Hofte, M. Caboche, and J. Traas, Cell Biol. Int., 1993, 17, 1013.

2.. M. D. Fricker and N. S. White, J. Microsc., 1992, 166, 29.

3. S. K. Lam, Y. C. Tse, D. G. Robinson, L. Jiang, Trends Plant Sci., 2007, 12, 497.

4. Y. C. Tse, S. K. Lam, and L. Jiang, J Plant Biol., 2009, 52, 1.

5. F. Brandizzi, S. L. Irons, J. Johansen, A. Kotzer, and U. Neumann, J. Microsc., 2004, 214, 138.

6. (a) S. J. Butler and D. Parker, Chem. Soc. Rev., 2013, 42, 1652; (b) S. V. Eliseeva and J.-C. G. Bünzli, Chem. Soc. Rev., 2010, 39, 189; (c) A. Thibon and V. C. Pierre, Anal. Bioanal. Chem., 2009, 394, 107; (d) C. P. Montgomery, B. S. Murray, E. J. New, R. Pal, and D. Parker, Acc. Chem. Res., 2009, 42, 925; (e) J.-C. G. Bünzli, Chem. Rev., 2010, 110, 2729.

7. (a) G. R. Motson, J. S. Fleming, and S. Brooker, in Advances in Inorganic Chemistry, Academic Press, 2004, 55, 361-432; (b) L. K. Truman, S. Comby and T. Gunnlaugsson, Angew. Chem., Int. Ed., 2012, 51, 9624; (c) M. Liu, Z. Ye, C. Xin and J. Yuan, Anal. Chim. Acta, 2013, 761, 149; (d) S. Shinoda and H. Tsukube, Analyst, 2011, 136, 431; (e) L. N. Sun, H. Peng, M. I. J. Stich, D. Achotz and O. S. Wolfbeis, Chem. Commun., 2009, 5000.

8. (a) H. Sigel, Metal Ions in Biological Systems: Volume 40: The Lanthanides and Their Interrelations with Biosystems, CRC Press, 1st ed., 2003; (b) S. Mohandessi, M. Rajendran, D. Magda and L. W. Miller, Chemistry-Eur. J., 2012, 18, 10825; (c) E. J. New, D. Parker, D. G. Smith, J. W. Walton, Curr. Opin. Chem. Biol., 2010, 14, 238.

9. M. Elbanowski and B. Makowska, J. Photochem. Photobiol., A, 1996, 99, 85.

10. (a) S. Aime, M. Botta, M. Fasano, E. Terreno, P. Kinchesh, L. Calabi, and L. Paleari, Magn. Reson. Med., 1996, 35, 648; (b) P. Harvey, A. M. Blamire, J. I. Wilson, A. M. Funk, K-L. N. A. Finney, P. K. Senanayake and D. Parker, Chem. Sci. $2013,4,4251$.

11. (a) K. Hanaoka, K. Kikuchi, S. Kobayashi, and T. Nagano, J. Am. Chem. Soc., 2007, 129, 13502; (b) H. E. Rajapakse, N. Gahlaut, S. Mohandessi, D. Yu, J. R. 
Turner and L. W. Miller, Proc. Natl. Acad. Sci. USA, 2010, 107, 13582; (c) D. G. Smith, B. K. McMahon, R. Pal and D. Parker, Chem. Commun., 2012, 48, 8520.

12. J. Yuan and G. Wang, TrAC, Trends Anal. Chem., 2006, 25, 490.

13. (a) R. Pal and D. Parker, Org. Biomol. Chem. 2008, 6, 1020; (b) B. K. McMahon, R. Pal, D. Parker, Chem. Commun. 2013, 49, 5363; (c) D. G. Smith, R. Pal and D. Parker, Chem.-Eur. J. 2012, 18, 11604.

14. J. Yu, D. Parker, R. Pal, R. A. Poole, and M. J. Cann, J. Am. Chem. Soc. 2006, 128, 2294.

15. R. A. Poole, G. Bobba, M. J. Cann, J.-C. Frias, D. Parker, and R. D. Peacock, Org.Biomol.Chem. 2005, 3, 1013.

16. J. C. Frias, G. Bobba, M. J. Cann, C. J. Hutchison, and D. Parker, Org. Biomol. Chem. 2003, 1, 905.

17. Y. Bretonniere, M. J. Cann, D. Parker, R. Slater, Org. Biomol. Chem. 2004, 2, 1624.

18. E. J. New and D. Parker, Org. Biomol. Chem. 2009, 7, 851.

19. E. J. New, A. Congreve and D. Parker, Chem. Sci., 2010, 1, 111.

20. K. M. David and C. Perrot-Rechenmann, Plant Physiol., 2001, 125, 1548.

21. L-O. Palsson, R. Pal, B. S. Murray, D. Parker and A. Beeby, Dalton Trans., 2007, 5726.

22. (a) P. Atkinson, K. S. Findlay, F. Kielar, R. Pal, D. Parker, R. A. Poole, H. Puschmann, S. L. Richardson, P. A. Stenson, A. L. Thompson, J. Yu, Org Biomol. Chem. 2006, 4, 1707; (b) G-L. Law, C. Man, D. Parker and J. W. Walton, Chem. Commun. 2010, 46, 2391.

23. R. Pal, D. Parker, L. C. Costello, Org. Biomol. Chem. 2009, 7, 1525.

24. S. J. Butler, R. Pal, L. Lamarque and D. Parker, Chem. Sci. 2014, 5, submitted, November 52013.

25. S. Bolte, C. Talbot, Y. Boutte, O. Catrice, N. D. Read, B. Satiat-Jeuenmaitre, J. Microscopy, 2004, 214, 159.

26. R. A. Van der Hoorn, F. Laurent, R. Roth, and P. J. De Wit, Mol. Plant Microbe Interact. 2000, 13, 439.

27. S. Y. Rhee, W. Beavis, T. Z. Berardini, G. Chen, D. Dixon, A. Doyle, M. GarciaHernandez, E. Huala, G. Lander, M. Montoya, N. Miller, L. A. Mueller, S. Mundodi, L. Reiser, J. Tacklind, D. C. Weems, Y. Wu, I. Xu, D. Yoo, J. Yoon, and P. Zhang, Nucl. Acids Res., 2003, 31, 224. 
28. S. L. Shaw, Plant J., 2006, 45, 573.

29. (a) J. C. Scaiano, D.Weldon, C.N. Pliva and L. J. Martinez, J. Phys. Chem. A, 1998, 102, 6898; (b) L. J. Martinez, J. C. Scaiano, J. Phys. Chem. A 1999, 103, 203. 